九州大学学術情報リポジトリ

Kyushu University Institutional Repository

\title{
Optimum Conditions for the Assay of Hemolytic Complement Titer of Porgy (Pagrus major) Serum
}

Matsuyama, Hiroko

Laboratory of Fisheries Chemistry, Faculty of Agriculture, Kyushu University

Hirata, Akira

Laboratory of Fisheries Chemistry, Faculty of Agriculture, Kyushu University

Nakao, Miki

Laboratory of Fisheries Chemistry, Faculty of Agriculture, Kyushu University

Yano, Tomoki

Laboratory of Fisheries Chemistry, Faculty of Agriculture, Kyushu University

https://doi.org/10.5109/23820

出版情報：九州大学大学院農学研究院紀要. 30 (2/3)，pp. 149-158，1985-12. Kyushu University バージョン：

権利関係: 
J. Fac. Agr., Kyushu Univ., 30 (2 • 3), 149-158 (1985)

\title{
Optimum Conditions for the Assay of Hemolytic Complement Titer of Porgy (Pagrus major) Serum
}

\author{
Hiroko Matsuyama, Akira Hirata, Miki Nakao and Tomoki Yano \\ Laboratory of Fisheries Chemistry, Faculty of Agricuture, \\ Kyushu University 46-04, Fukuoka 812 \\ (Received September 10, 1985)
}

\begin{abstract}
The optimum conditions for the titration of complement activity of porgy serum were examined by the use of sheep red blood cells (SRBC) sensitized with porgy antiserum. The antiserum was obtained from porgy immunized with SRBC stromata for 45 days, and heat-treated at $45^{\circ} \mathrm{C}$ for 20 min to inactivate the complement coexisting within the serum. The optimum conditions for the hemolytic complement reaction were found to be as follows: reaction temperature, $20^{\circ} \mathrm{C}$; reaction period, $2 \mathrm{~h} ; \mathrm{pH}, 7.0$ to 8.0 ; concentrations of $\mathrm{Ca}^{2+}$ and $\mathrm{Mg}^{2+}, 0.5$ to $1.0 \mathrm{mM}$ and $1.0 \mathrm{mM}$, respectively. The complement titer of porgy specimens which were obtained from a fish farm near Fukuoka City in August 1985 were assayed under these conditions. The titers ranged widely from 19.5 to $54.0 \mathrm{CH}_{50}$ units/ml, the mean value being $29.2 \mathrm{CH}$, units/ml. It was found that porgy complement is quite labile compared with mammalian and carp complements. Porgy complement lost its hemolytic activity within $24 \mathrm{~h}$.
\end{abstract}

\section{INTRODUCTION}

Hemolytic complement activity of mammals is usually assayed by Mayer's method (1961) : the complement is incubated with sensitized sheep red blood cells $\left(5 \times 10^{8}\right.$ cells) in $7.5 \mathrm{ml}$ of isotonic buffer (pH 7.4), containing $0.15 \mathrm{mM}$ $\mathrm{Ca}^{2+}$ and $0.50 \mathrm{mM} \mathrm{Mg}{ }^{2+}$, at $37^{\circ} \mathrm{C}$ for $60 \mathrm{~min}$; one unit of $\mathrm{CH}_{50}$ is defined as the amount of complement which hemolyzes $50 \%$ of the total cells.

Recently, the amount of literature concerned with fish complement has increased as more attention has become focussed on the defense mechanisms of lower vertebrates, and most classes of fish have been shown to possess a complement system which resembles that of mammals. Included in this literature, have been reports describing the measurement of fish complement activity by Mayer's method with modifications of the temperature and/or period of incubation. For example, Legler and Evans (1967) incubated sensitized SRBC with fish! complement at $28^{\circ} \mathrm{C}$ for $2 \mathrm{~h}$; Legler et al. (1971) assayed the complement activity of paddlefish at $25^{\circ} \mathrm{C}$ for $4 \mathrm{~h}$; Sakai (1981) titrated the complement activity of salmonid fishes at $30^{\circ} \mathrm{C}$ for $60 \mathrm{~min}$; Nonaka \& al. (1981) carried out an assay of the complement activity of rainbow trout at $25^{\circ} \mathrm{C}$ for $60 \mathrm{~min}$. However, as far as we are aware, the effects of $\mathrm{pH}$ and concentrations of $\mathrm{Ca}^{2+}$ and $\mathrm{Mg}^{2+}$ on the hemolytic activity of fish have not been fully investigated. 
In our previous report (Yano et al.,1984), we examined the optimum conditions for the assay of the complement titer of carp. In this paper, we deal with the titration of the complement activity of the porgy, a marine fish, which is now extensively cultivated in Japan.

\section{MATERIALS AND METHODS}

\section{Reagents}

The sources of reagents used in the present work were as follows: EDTA and barbital sodium, Wako Pure Chemical Industries Co., Osaka; MS-222 (tricain methanesulfonate), Sankyo Co., Tokyo; Amberlite IRC-50, Organo Co., Tokyo; sheep blood in Alsever's solution, Japan Bio-Supply Center, Tokyo.

The buffers used in the experiment and their abbreviations were: $\mathrm{GVB}^{2+}$, veronal-buffered saline, $\mathrm{pH} 7.4$, containing $0.1 \%$ gelatin, $0.15 \mathrm{mM} \mathrm{CaCl}_{2}$ and

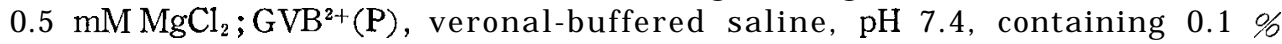
gelation, $1.0 \mathrm{mM} \mathrm{CaCl}_{2}$ and $1.0 \mathrm{mM} \mathrm{MgCl}_{2}$; EDTA . GVB, veronal-buffered saline containing $0.1 \%$ gelatin and $0.01 \mathrm{M}$ EDTA; GGVB, veronal-buffered saline containing $2.5 \%$ glucose and $0.1 \%$ gelatin; $\mathrm{GVB}(\mathrm{f})$, veronal-buffered saline containing $0.1 \%$ gelation, free from divalent cations. $\mathrm{GVB}(\mathrm{f})$ was made by passing $200 \mathrm{ml}$ of veronal-buffered saline containing $0.1 \%$ gelatin through Amberlite IRC-50 $(5 \mathrm{ml})$ and readjusting its $\mathrm{pH}$ to 7.4 . Unless otherwise noted, $\mathrm{GVB}^{2+}$ was used throughout this experiment.

\section{Fish}

Specimens of porgy, Pagrus major, weighing 450 to $500 \mathrm{~g}$, were purchased from a fish farm near Fukuoka City, and maintained in aquaria for about one month at a water temperature of $18^{\circ} \pm 1^{\circ} \mathrm{C}$ under a photoregime of $12 \mathrm{~L} / 12 \mathrm{D}$.

\section{Immunization of fish}

A sheep red blood cell (SRBC) stroma suspension was prepared by the method described in the previous paper (Yano et al., 1984). Every 5 to 7 days, 4 porgys were intraperitoneally injected with this suspension $(0.2 \mathrm{ml} / \mathrm{fish})$, and at the same time, $0.5 \mathrm{ml}$ of blood was collected from the dorsal aorta of each fish to measure the antibody titer (hemolysin titer). The blood was coagulated at $20^{\circ} \mathrm{C}$ for $30 \mathrm{~min}$, cooled in ice-water for $1 \mathrm{~h}$, and centrifuged at $3000 \mathrm{rpm}$ for $5 \mathrm{~min}$. The serum obtained was stored at $-30^{\circ} \mathrm{C}$ until use.

Injection of the stroma suspension was repeated 7 times, while the blood collection was repeated 8 times (until 45 days after the first injection).

\section{Collection of antiserum and normal serum}

On the last day of the above experiment (the 45 th day of immunization), porgys were anesthetized with MS-222, and ca. $5 \mathrm{ml}$ of blood was collected from the dorsal aorta of each fish using tuberculin syringes. The blood was allowed to clot at $20^{\circ} \mathrm{C}$ for $30 \mathrm{~min}$, and cooled at $0^{\circ} \mathrm{C}$ for $1 \mathrm{~h}$. After centrifuging at $3000 \mathrm{rpm}$ for $5 \mathrm{~min}$, the supernatant, anti-SRBC porgy serum, was stored at $-30^{\circ} \mathrm{C}$ until use. 
Normal porgy serum was collected as a source of complement in a similar manner to that from uninjected fishes, and stored at $-30^{\circ} \mathrm{C}$. Both porgy antiserum and normal serum were stable for at least one month at $-30^{\circ} \mathrm{C}$.

\section{Heat inactivation of complement}

Anti-SRBC porgy serum was diluted $1 / 40$ with $\mathrm{GVB}^{2+}$, and 0.5 -ml aliquots of the dilution were heated at $25^{\circ}, 30^{\circ}, 43^{\circ}, 45^{\prime \prime}$ and $50^{\circ} \mathrm{C}$ each for $20 \mathrm{~min}$ in a small test tube. To each tube, $0.1 \mathrm{ml}$ of $\mathrm{SRBC}$ suspension $\left(1 \times 10^{9} \mathrm{cells} / \mathrm{ml}\right)$ and $0.9 \mathrm{ml}$ of $\mathrm{GVB}^{2+}$ were added, and the mixture was further incubated at $20^{\circ} \mathrm{C}$ for $90 \mathrm{~min}$. After centrifugation, the hemolysis rate was calculated from the $\mathrm{OD}_{541}$ of the supernatant fluid.

\section{Preparation of sensitized sheep red blood cells (EA)}

SRBC were washed twice with GVB(f) and suspended at a concentration of $1 \times 10^{9}$ cells $/ \mathrm{ml}$ in the same buffer. Anti-SRBC porgy serum, which had been heat-treated at $45^{\circ} \mathrm{C}$ for $20 \mathrm{~min}$, was diluted to between $1 / 50$ and $1 / 100$ with EDTA . GVB (the dilution for the optimum sensitization was determined in the usual way). Equal volumes of SRBC suspension and of the diluted antiserum were mixed and incubated at $20^{\circ} \mathrm{C}$ for $30 \mathrm{~min}$ with occasional shaking. Then the mixture was centrifuged at $2000 \mathrm{rpm}$ for $3 \mathrm{~min}$ and the precipitate (EA) was washed well with GVB(f). Finally, EA cells were suspended in GGVB to give a cell density of $5 \times 10^{8} / \mathrm{ml}$ and stored at $0^{\circ} \mathrm{C}$. Just before use, the EA cells were washed and resuspended in $\mathrm{GVB}^{2+}$ or GVB(f).

\section{Determination of the optimum conditions for the hemolytic reaction}

(a) reaction temperature

Hemolytic reaction was carried out by reducing the total volume used in Mayer's method $(7.5 \mathrm{ml})$ to one fifth $(1.5 \mathrm{ml})$. The reaction mixture, containing $0.2 \mathrm{ml}$ of EA suspension $\left(5 \times 10^{8} / \mathrm{ml}\right), 0.5 \mathrm{ml}$ of diluted porgy serum and $0.8 \mathrm{ml}$ of $\mathrm{GVB}^{2+}$, was incubated at $10^{\circ}, 20^{\circ}, 25^{\circ}, 30^{\prime \prime}$ and $37^{\circ} \mathrm{C}$ for $90 \mathrm{~min}$, followed by cooling at $0^{\circ} \mathrm{C}$ and centrifuged at $3000 \mathrm{rpm}$ for $5 \mathrm{~min}$. Hemolysis rate at each temperature was calculated from the $O D_{541}$ of the supernatant.

(b) $\mathrm{pH}$

The $\mathrm{pH}$ of $\mathrm{GVB}^{2+}$ was altered to $6.0,6.5,7.0,7.5,8.0,8.5,9.0$ and 9.5 by adding $1 \mathrm{~N} \mathrm{HCI}$ or $1 \mathrm{~N} \mathrm{NaOH}$, and hemolytic reaction was carried out at each $\mathrm{pH}$. The reaction mixtures were incubated at $20^{\circ} \mathrm{C}$ for $90 \mathrm{~min}$ and centrifuged, and the hemolysis rate at each $\mathrm{pH}$ was calculated from the $\mathrm{OD}_{541}$ of the supernatant.

( c) incubation period

The hemolytic reaction mixtures were incubated at $20^{\circ} \mathrm{C}$ for $150 \mathrm{~min}$ in small test tubes. Every 10 to 20 min during incubation, a test tube was taken out and centrifuged. Hemolysis rate at each time point was calculated from the $\mathrm{OD}_{541}$ of the supernatant and plotted on graph paper to follow up the time course of hemolysis.

(d) concentrations of $\mathrm{Ca}^{2+}$ and $\mathrm{Mg}^{2+}$

In order to remove as much $\mathrm{Ca}^{2+}$ and $\mathrm{Mg}^{2+}$ as possible, $0.5 \mathrm{ml}$ of porgy 
serum (ca. $20 \mathrm{CH}_{50}$ units $/ \mathrm{ml}$ ) was passed through an Amberlite IRC-50 (3 ml), then $2.8 \mathrm{ml}$ of $\mathrm{GVB}(\mathrm{f})$ was added to the column; the first eluate $(0.3 \mathrm{ml})$ was discarded and the next eluate $(2.5 \mathrm{ml})$ was collected. This eluate was further diluted $1 / 4$ with GVB(f).

A $0.5-\mathrm{ml}$ aliquot of the diluted eluate and $10 \mu \mathrm{l}$ of $\mathrm{CaCl}_{2}$ and $10 \mu \mathrm{lof} \mathrm{MgCl}_{2}$ were added to $0.2 \mathrm{ml}$ of EA suspension in $\mathrm{GVB}(\mathrm{f})$, and the total volume was made up to $1.5 \mathrm{ml}$ with $\mathrm{GVB}(\mathrm{f})$. The optimum concentration of $\mathrm{Ca}^{2+}$ was examined in the presence of $0.50 \mathrm{mM} \mathrm{Mg}^{2+}$, whereas that of $\mathrm{Mg}^{2+}$ was investigated in the presence of $0.15 \mathrm{mM} \mathrm{Ca}^{2+}$. The mixtures were incubated at $20^{\circ} \mathrm{C}$ for $90 \mathrm{~min}$, and centrifuged to estimate the hemolysis rates.

\section{Assay of complement titer $\left(\mathrm{CH}_{80}\right.$ unit/ml)}

For assaying the hemolytic complement titer of porgy, $\mathrm{GVB}^{2+}(\mathrm{P})$ was used instead of $\mathrm{GVB}^{2+}$. To $0.2 \mathrm{ml}$ of EA suspension $\left(5 \times 10^{8} / \mathrm{ml}\right)$ was added $0.3,0.5$ or $0.7 \mathrm{ml}$ of diluted porgy serum (1/25 to $1 / 35)$, then the total volume was adjusted to $1.5 \mathrm{ml}$ with $\mathrm{GVB}^{2+}(\mathrm{P})$. The mixture was incubated at $20^{\circ} \mathrm{C}$ for $120 \mathrm{~min}$ and centrifuged. The hemolysis rate was estimated from the $\mathrm{OD}_{541}$ of the supernatant and the complement titer $\left(\mathrm{CH}_{50} \mathrm{unit} / \mathrm{ml}\right)$ was calculated according to the method of Mayer (1961).

\section{Assay of hemolysin titer}

Anti-SRBC porgy serum was heat-treated at $45^{\circ} \mathrm{C}$ for 20 min and diluted with $\mathrm{GVB}^{2+}(\mathrm{P})$ in a two-fold manner $(1 / 50,1 / 100,1 / 200 \ldots)$ at a volume of 0.5 $\mathrm{ml}$ in small test tubes, then $0.1 \mathrm{ml}$ of SRBC suspension $\left(1 \times 10^{9} / \mathrm{ml}\right)$ was added to each tube. After incubation at $20^{\circ} \mathrm{C}$ for $10 \mathrm{~min}, 0.5 \mathrm{ml}$ of optimally diluted normal porgy serum (ca. 1/50) and $0.4 \mathrm{ml} \mathrm{of} \mathrm{GVB}^{2+}(\mathrm{P}$ ) were added, and the reaction mixture was further incubated at $20^{\circ} \mathrm{C}$ for $120 \mathrm{~min}$. After centrifuga. tion at $3000 \mathrm{rpm}$ for $5 \mathrm{~min}$, the hemolysis rate (y) was plotted on semi-logarithmic graph paper (the logarithmic $\mathrm{X}$-axis representing the dilution of hemolysin, the Y-axis representing y). Hemolysin titer, the dilution giving 50 \% hemolysis $(y=0.5)$, was read off from the graph.

\section{RESULTS}

\section{Anti-SRBC porgy serum}

Four porgys were injected intraperitoneally with $0.2 \mathrm{ml}$ of SRBC stroma suspension 7 times at intervals of 5 to 7 days, and the change of hemolysin titer occurred during immunization was observed (Fig. 1). The hemolysin titer of the fish began to rise on the 25 th day of immunization and reached a high value (1300 to 15000$)$ on the 45 th day.

\section{Heat treatment of porgy antiserum}

In order to determine the optimum condition for the heat inactivation of the complement coexisting within antiserum, anti-SRBC porgy serum was heated at various temperatures for $20 \mathrm{~min}$, and the remaining hemolytic activity was assayed by incubating the heat-treated serum with SRBC. 


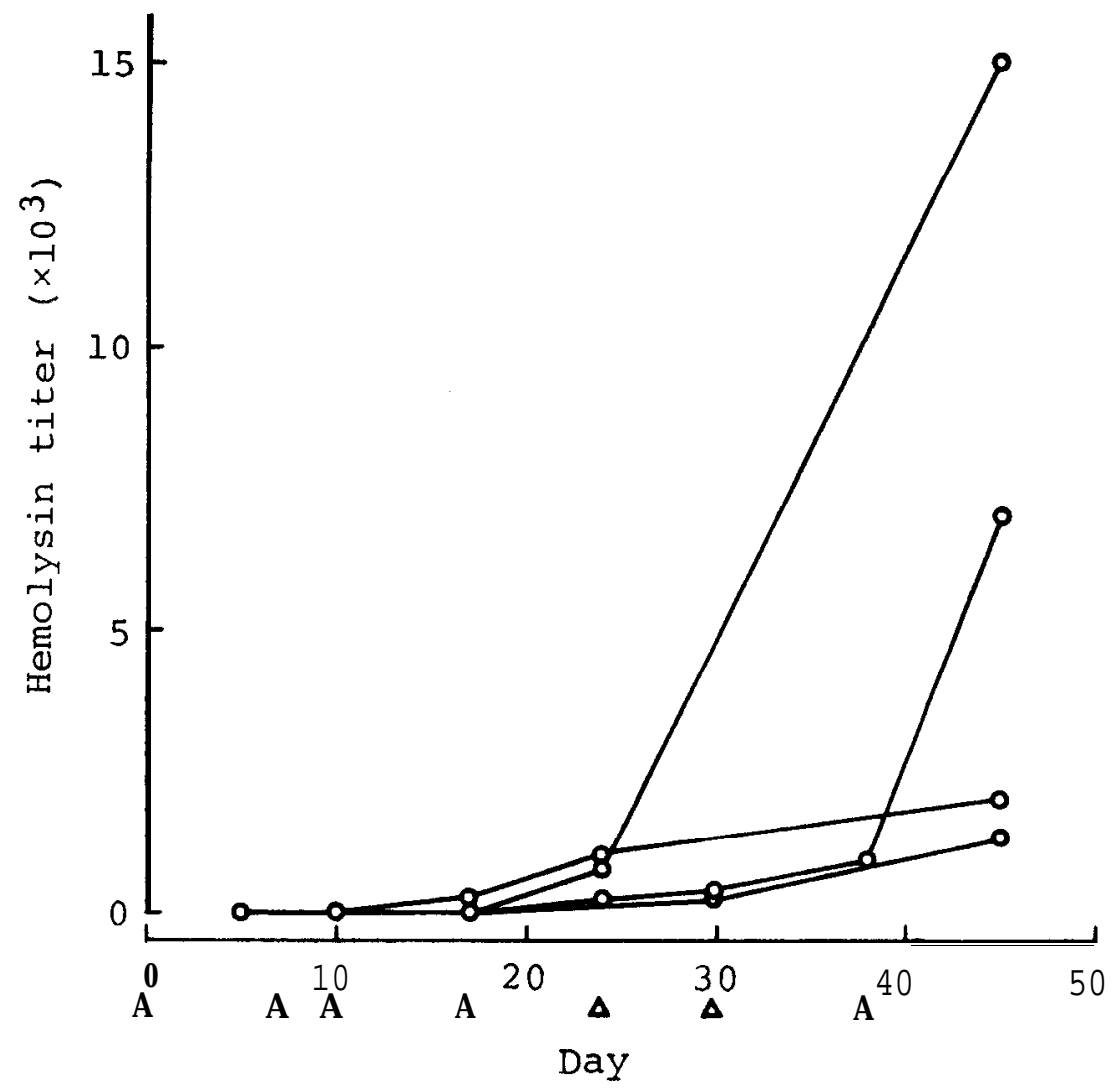

Fig. 1. Changes in the hemolysin titers of 4 porgys injected with SRBC stroma suspension (1 $\mathrm{mgN} / \mathrm{ml})$.

Triangles indicate the days of injection $(0.2 \mathrm{ml} / \mathrm{fish})$. On the 45 th day of immunization, all fish were bled and antisera were stored at $-30^{\circ} \mathrm{C}$.

As shown in Fig. 2, porgy complement was found to be completely inactivated by heating at $45^{\circ} \mathrm{C}$ for $20 \mathrm{~min}$.

\section{0 ptimum conditions for the assay of complement titer}

The total volume of the reaction mixture used in Mayer's method was reduced to $1 / 5$, and incubation was carried out at various temperatures for 90 min. As shown in Fig. 3, the porgy complement maintained high activity over the range of $20^{\prime \prime}$ to $30^{\circ} \mathrm{C}$, and the highest activity was obtained at $20^{\circ} \mathrm{C}$.

Fig. 4 shows the effect of $\mathrm{pH}$ on the activity of porgy complement. The optimum $\mathrm{pH}$ lay between $\mathrm{pH} 7.0$ and 8.0, and at lower or higher $\mathrm{pH}$ values, the activity of porgy complement diminished.

Fig. 5 shows the time course of hemolysis by porgy complement. It was found that hemolysis takes place rather slowly, reaching an end-point in about $120 \mathrm{~min}$. 


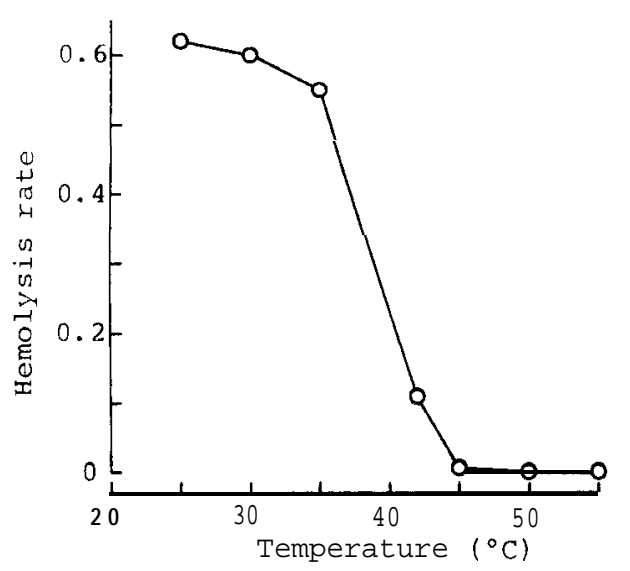

Fig. 2. Heat inactivation of porgy complement.

Anti-SRBC porgy serum was heated at $30^{\prime \prime}$ to $50^{\circ} \mathrm{C}$ for $20 \mathrm{~min}$, and the remaining hemolytic activity was assayed by incubating with SRBC at $20^{\circ} \mathrm{C}$ for $90 \mathrm{~min}$ at $\mathrm{pH} 7.4$.

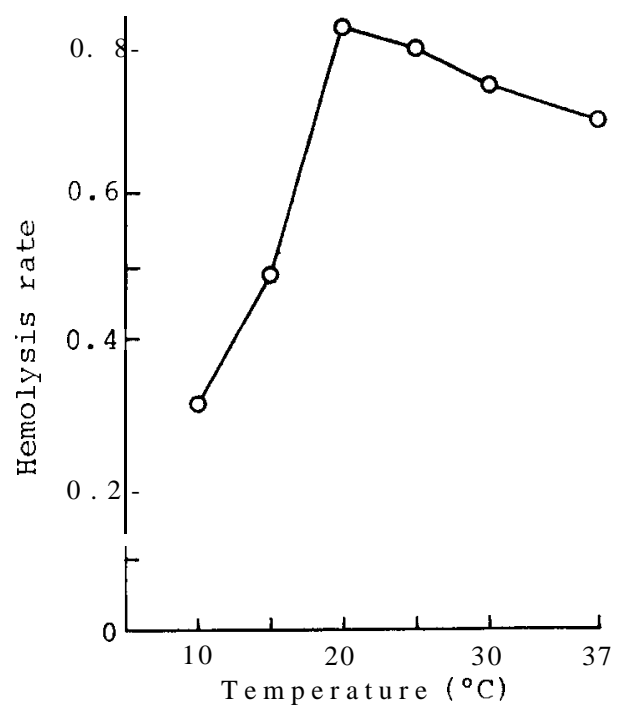

Fig. 3. Effect of incubation temperature on the hemolytic activity of porgy complement.

The reaction was carried out at $10^{\prime}$ to $37^{\circ} \mathrm{C}$ for 90 min at $\mathrm{pH} \mathrm{7.4}$.

The effect of concentrations of divalent cations on the complement activity was then investigated. As shown in Fig. 6, the optimum concentration of $\mathrm{Ca}^{2+}$ was 0.5 to $1.0 \mathrm{mM}$ and that of $\mathrm{Mg}^{2+}$ was $1.0 \mathrm{mM}$.

In conclusion, the titration of porgy complement necessitates some modifications of Mayer's method, that is, incubation should be carried out at $20^{\circ} \mathrm{C}$ 


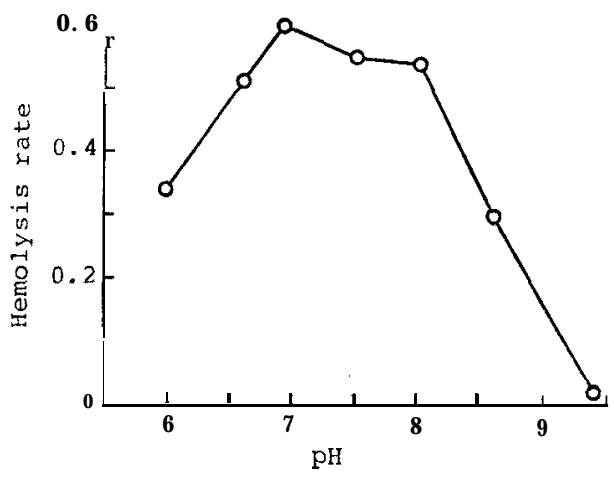

Fig. 4. Effect of $\mathrm{pH}$ on the hemolytic activity of porgy complement. The reaction was carried out at $20^{\circ} \mathrm{C}$ for $90 \mathrm{~min}$.

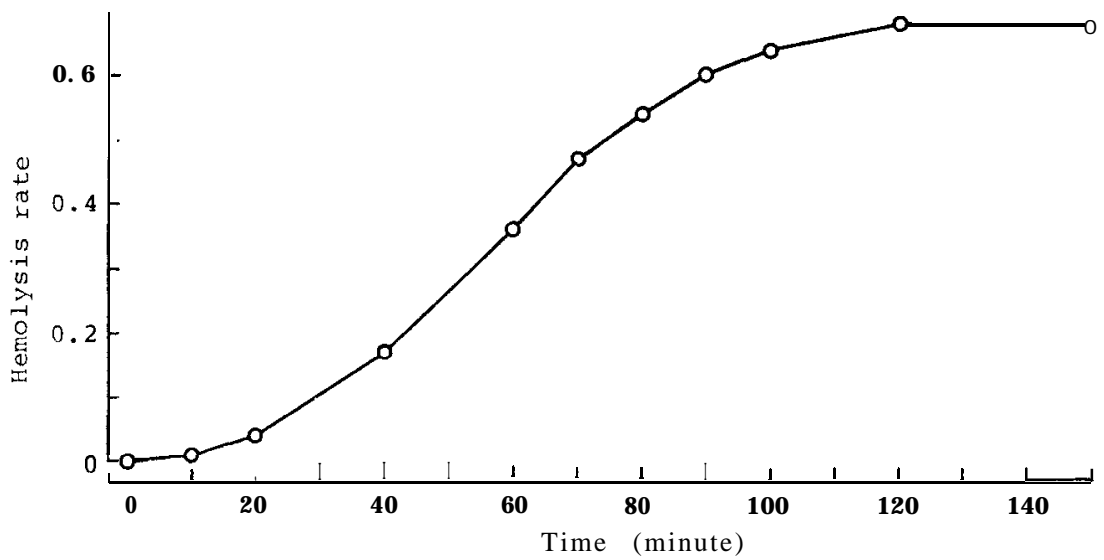

Fig. 5. Time course of hemolysis in the reaction of porgy complement with sensitized SRBC.

The reaction was performed at $20^{\circ} \mathrm{C}$ for $150 \mathrm{~min}$ at $\mathrm{pH}$ 7. 4 .

for $120 \mathrm{~min}$ at $\mathrm{pH} 7.4$ in the presence of $1.0 \mathrm{mM} \mathrm{Ca}^{2+}$ and $1.0 \mathrm{mM} \mathrm{Mg}^{2+}$.

Under these conditions, the complement titer of 8 porgy specimens which were obtained from a fish farm near Fukuoka City in August 1985 were assayed. The titers ranged widely from 19.5 to $54.0 \mathrm{CH}_{50}$ units $/ \mathrm{ml}$, the mean value being $29.2 \mathrm{CH}$, units $/ \mathrm{ml}$.

\section{Stability of porgy complement}

An experiment was performed to check the stability of porgy complement. The porgy sera stored at $-30^{\circ} \mathrm{C}$ were thawed at room temperature and then allowed to stand at $0^{\circ} \mathrm{C}$ or $20^{\circ} \mathrm{C}$ for $24 \mathrm{~h}$. Hemolytic activity was measured at 3 , 6,12 and $24 \mathrm{~h}$ after thawing (Fig. 7). Within $3 \mathrm{~h}$, the decreases in hemolytic activity were less than $5 \%$ at both temperatures. However, this was followed 


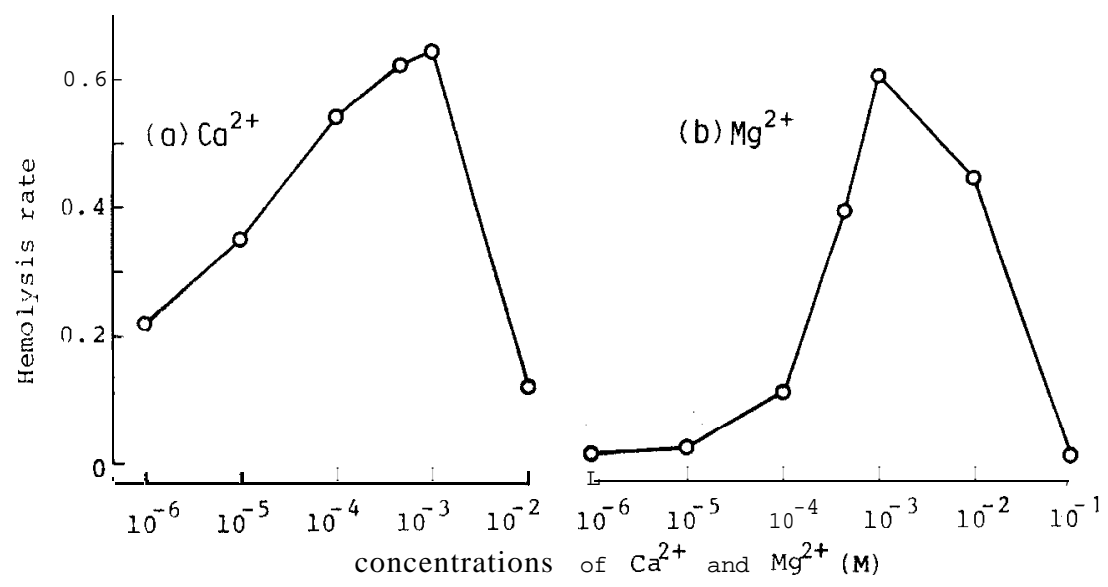

Fig. 6. Effect of concentration of $\mathrm{Ca}^{2+}$ or $\mathrm{Mg}^{2+}$ on the hemolytic activity of porgy complement.

The reaction was performed at $20^{\circ} \mathrm{C}$ for $90 \mathrm{~min}$ at $\mathrm{pH} 7.4$.

(a) Concentration of $\mathrm{Ca}^{2+}$ was altered in the presence of $0.5 \mathrm{mM} \mathrm{MgCl}$.

(b) Concentration of $\mathrm{Mg}^{2+}$ was altered in the presence of $0.15 \mathrm{mM} \mathrm{CaCl}_{2}$.

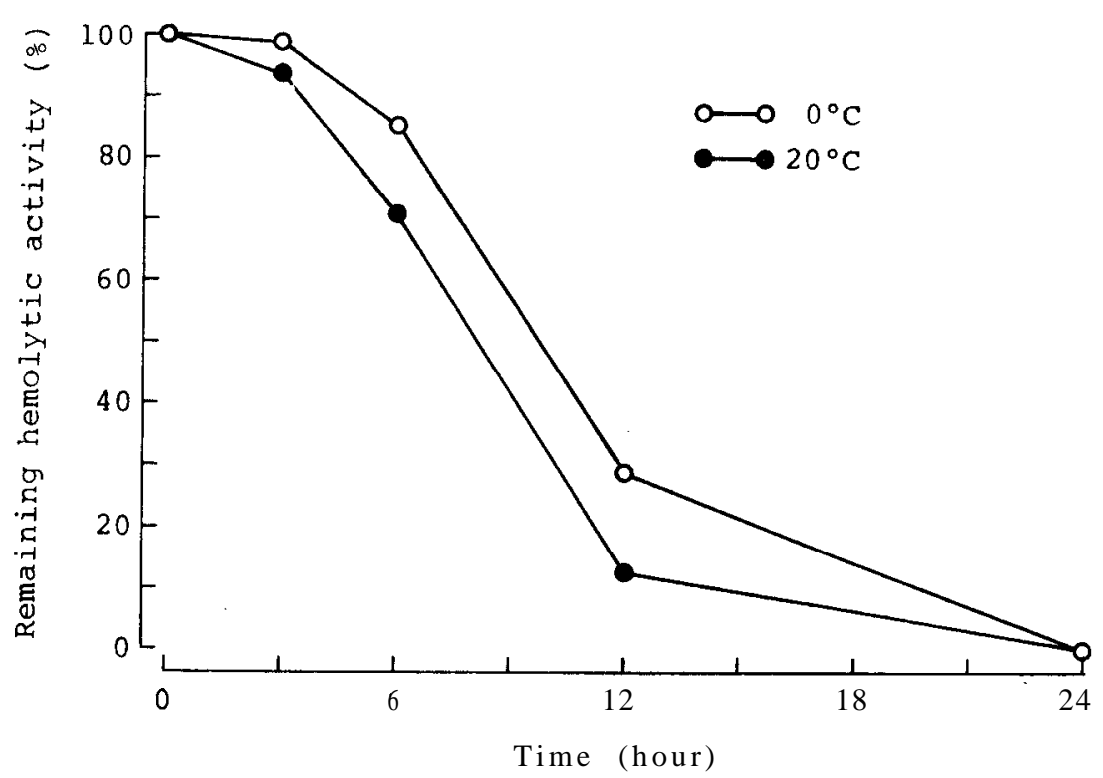

Fig. 7. Stability of porgy complement.

Porgy serum which had been stored at $-30^{\circ} \mathrm{C}$ was thawed at room temperature and allowed to stand at $0^{\circ} \mathrm{C}$ or $20^{\circ} \mathrm{C}$ for $24 \mathrm{~h}$. Residual hemolytic activity was expressed as a percentage of the initial one.

by a drop in the activities, i. e., after $12 \mathrm{~h}$ the sample kept at $0^{\circ} \mathrm{C}$ showed about a $70 \%$ decrease in activity, while that kept at $20^{\circ} \mathrm{C}$ showed an $86 \%$ de- 
crease. By the end of the experiment, the samples completely lost their activities.

\section{DISCUSSION}

In preliminary experiments, we first attempted to use SRBC sensitized with carp antibody for the titration of porgy complement, as we had prepared carp antibody in the previous study (Yano et al., 1984), but carp antibody was found to be incompatible with porgy complement. Therefore, we prepared anti-SRBC porgy serum by immunizing porgy against SRBC.

The increase in the hemolysin titer of porgy was considerably slower than that of carp. As shown in Fig. 1, the hemolysin titer of porgy began to increase on the 25 th day of immunization and was still increasing at the end of the experiment, while that of carp began to increase on the 15 th day and reached its peak on the 25 th day (Yano et al., 1984). This delay in antibody production of porgy is probably attributable to the difference in water temperature of the aquaria $\left(18^{\circ} \mathrm{C}\right.$ for porgy, $24^{\circ} \mathrm{C}$ for carp), because antibody production of fish is said to be temperature-dependent (Avtalion et al., 1973; Tait, 1969 ; Harris, 1973 ; Rijkers et al., 1980).

We have reported in the previous paper that the complement activity of carp can be assayed by Mayer's method if its incubation temperature is modified from $37^{\circ} \mathrm{C}$ to $30^{\circ} \mathrm{C}$. However, the present work revealed that the titration of porgy complement necessitates some other modifications. (1) The incubation temperature should be lowered from $37^{\circ} \mathrm{C}$ to $20^{\circ} \mathrm{C}$. (2) The incubation period should be extended from $60 \mathrm{~min}$ to $120 \mathrm{~min}$, because the hemolytic reaction by porgy complement takes place slowly even at the optimum temperature $\left(20^{\circ} \mathrm{C}\right)$. (3) The concentration of $\mathrm{Ca}^{2+}$ should be changed from $0.15 \mathrm{mM}$ to $1.0 \mathrm{mM}$, and that of $\mathrm{Mg}^{2+}$ should be altered from $0.5 \mathrm{mM}$ to $1.0 \mathrm{mM}$. These high requirements of $\mathrm{Ca}^{2+}$ and $\mathrm{Mg}^{2+}$ of porgy complement may reflect the high levels of concentration of these cations in porgy serum: porgy serum contained $2.90 \mathrm{mM} \mathrm{Ca}^{2+}$ and $1.63 \mathrm{mM} \mathrm{Mg}^{2+}$, whereas carp serum contained $2.30 \mathrm{mM} \mathrm{Ca}^{2+}$ and $1.28 \mathrm{mM} \mathrm{Mg}^{2+}$ (Yano et al., unpublished).

Finally, it must be noted that porgy complement is quite labile. When porgy serum was allowed to stand at $0^{\circ} \mathrm{C}$, it showed a $15 \%$ decrease in complement activity in $6 \mathrm{~h}$, whereas the activity of carp complement decreased by less than $5 \%$ within $6 \mathrm{~h}$. We therefore paid careful attention to use the porgy serum as soon as possible after thawing it.

\section{REFERENCES}

Avtalion, R. R., A. Wojdani, Z. Malik, R. Shahrabani and M. Duczyminer 1973 Influence of environmental temperature on the immune response in fish. Curr.Top.Microbiol. Immunol., 61: 1-35

Harris, J. E. 1973 The immune response of dace,Leuciscusleuciscus (L.) to injected antigenic materials. J. Fish. Biol., 5: 261-276

Legler, D. W. and E. E. Evance 1967 Comparative immunology: serum complement of 
freshwater fishes. Trans. Am. Fish. Soc., 96: 237-242

Legler, D. W., P. F. Weinheimer, R. T. Acton, H. K. Dupree, and T. R. Russell 1971

Humoral immune factors in the paddlefish, Polydon spathula. Comp. Biochem. Physiol., 38 B : $523-527$

Mayer, M. M. 1961 Complement and complement fixation. In "Experimental Immunochemistry", 2 nd ed. by E. A. Kabat and M. M. Mayer, Thomas Springfield, Ill., pp. 133240.

Nonaka, M., N. Yamaguchi, S. Natsuume-Sakai and M. Takahashi 1981 The complement system of rainbow trout (Salmo gairdneri) I. Identification of the serum lytic system homologous to mammalian complement. J.Immunol, $126: 1489-1494$

Rijkers, G. T., E. M. H. Frederix-Wolters and W. B. von Muiswinkel 1980 The immune system of cyprinid fish. Kinetics and temperature dependence of antibody-producing cells in carp (Cyprinus carpio). Immunology, 41: 91-97

Sakai, D. K. 1981 Spontaneous and antibody-dependent hemolysis activities of fish sera and inapplicability of mammalian complements to the immune hemolysis reaction of fishes. Bull. Japan. Soc.Sci. Fish., 47 : 979-991

Tait, N. N. 1969 The effect of temperature on the immune response in cold-blooded vertebrates. Physiol. Zool., 42: 29-35

Yano, T., H. Ando and M. Nakao 1984 Optimum conditions for the assay of hemolytic complement titer of carp and seasonal variation of the titers. J. Fac. Agr., Ky ushu Univ., 29: 91-101 